\title{
$\mathrm{CI}$ 툴을 이용한 해양소프트웨어품질 맞춤형 프로세스 사례
}

\author{
임상우*, 김길용**, 이서정***
}

요 약

국제해사기구에서는 e-Navigation의 개발과정에 소프트웨어 품질에 대한 고려가 필수적으로 도입될 수 있도록 해양소프트웨어품질보증을 진행해오고 있다. 소프트웨어 품질 확보를 위해서는 소프트웨어 개발 프로젝트 전반에 걸쳐 정해진 절차를 따르고, 각 절차를 수행한 결과로 산출물의 작성이 필요하다. 이를 지 원하는 도구의 활용은 소프트웨어 개발의 생산성에 중요한 요소가 될 수 있다. 본 논문에서는 실시간 모니 터링과 문서의 자동화가 가능한 도구를 활용하여 해양 소프트웨어 개발에 적용하기 위한 사례를 소개한다. 도구 활용에 대한 기대효과 및 해양 $\mathrm{SQA}$ 에 적용하기 위한 절차의 개선에 대해서 논의한다. 개선된 절차를 도구에 반영하여 해양 $\mathrm{SQA}$ 에 맞춤형 도구를 개발하는 것을 향후 목표로 한다.

키워드 : 해양 소프트웨어, 자동화도구, SQA, 소프트웨어 품질보증

\section{Case study of customizing a Continous Integration Tool for Maritime Software}

\author{
Sangwoo Lim*, Kilyong Kim**, Seojeong Lee***
}

\begin{abstract}
IMO has been proceeding in the maritime SQA for software quality is considered to be essential for the development of the introduction of the e-Navigation In order to ensure software quality, follow the prescribed procedures throughout the software development project and create the output as a result of executing the respective steps. This paper is introduced a case for applying to maritime software development using the tool that is capable of real-time monitoring and automated documentation. Also, It is discussed the improvement of procedures for applying the expected effects and maritime SQA for the tool utilization. The Development of customized tools for maritime SQA that is reflected an improved procedure for tool is the future goals.
\end{abstract}

Keywords : Maritime Software, Automated tTool, Continous Integration, Software Qaulity Assurance, e-Navigation

※ Corresponding Author: Seojeong Lee

Received : December 01, 2015

Revised : December 25, 2015

Accepted : December 28, 2015

* Graduated school of Korea Maritime and Ocean University, Department of Computer Engineering

** GMT, InC

$\star \star \star$ Korea Maritime and Ocean University, Division of Maritime IT Engineering

Tel: $+82-51-405-4888$

email:kmousqa@gmail.com

$\square$ This Research is the outcome of the 'Base Study of Marine Accident Prevention System (Phase 2)'

\section{Introduction}

E-Navigation is a policy started as a public agenda in the 81th meeting in the Maritime Safety Committee (MSC) of International Maritime Organization (IMO) in 2005 and has

project sponsored by the Korean Ministry of Ocean and Fisheries.

- This Research is the outcome of the 'The New Product/Technology Development Projects with a Purchase Condition' project sponsored by the Small and Medium Business Administration. 
(Figure 1) Overview of Software Quality activities for e-navigation systems

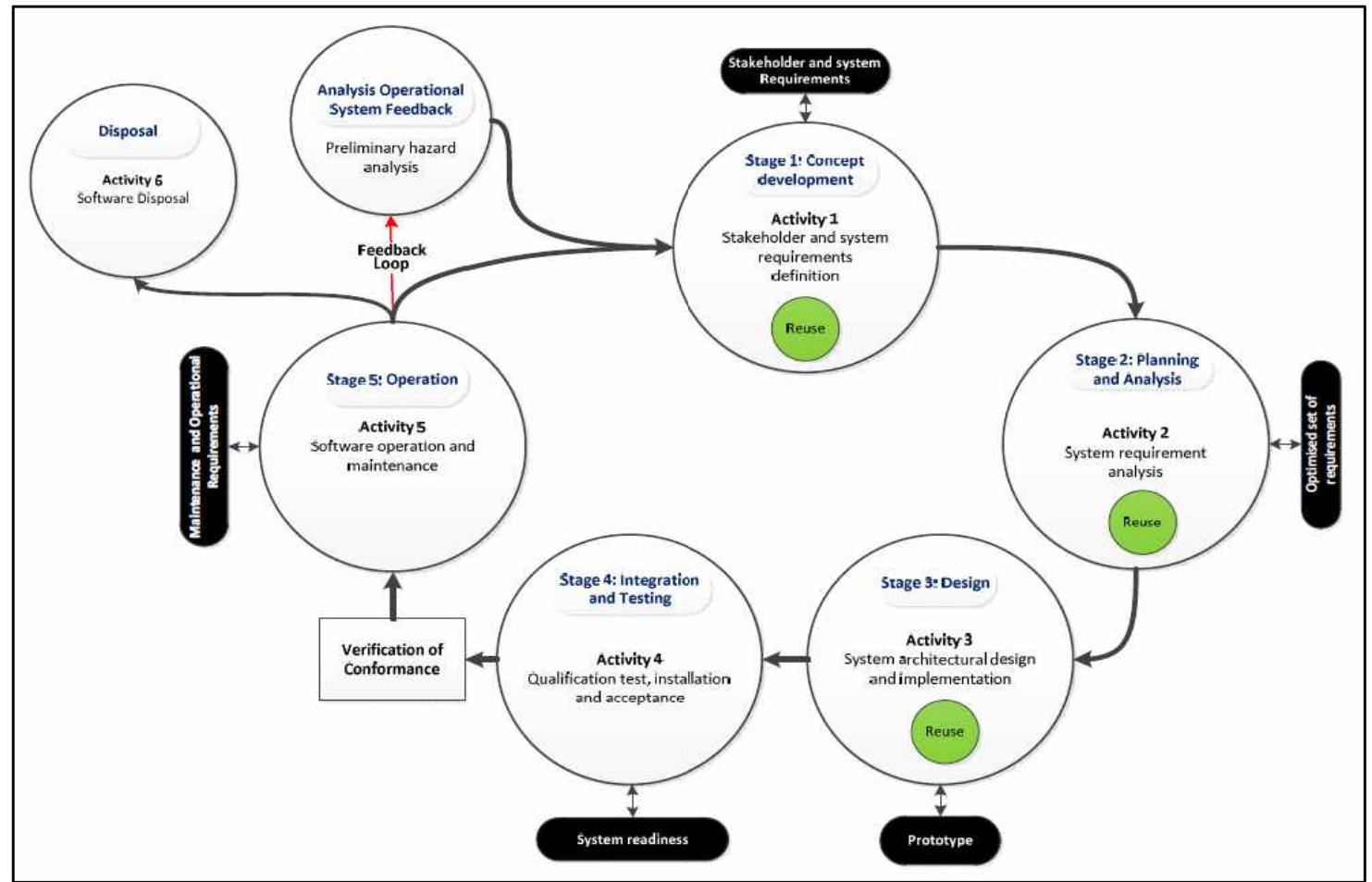

been continuously discussed to actively perform strategies from 2018. IMO has been continuously proceeding to make it inevitable to consider software quality in the development procedure of $\mathrm{e}^{-N a v i g a t i o n}$ in maritime Software Quality Assurance (SQA). Maritime SQA is different from the existing industrial SQA as it deals with data quality in the system and quality of usage for equipment and service more importantly. There is a need to establish processes by considering them.

This paper is intended to introduce a case of utilization of Continuous Integration (CI) tool for supporting the integrated management and operation of IT among all other tools previously used in the past and a case of application of it on the development of maritime software. In addition, it aims to derive the improvements on CI tools through the application of pilot project and make them as a customized tool for maritime SQA in the future as an ultimate goal.

\section{Related Studies}

\subsection{Maritime SQA}

In order to utilize a tool on the maritime SQA, it is required to refer to standards needed for application of SW in the field of maritime. However, according to the characteristics of IMO documents, it is difficult to apply proclamatory parts to the field of industry. Therefore, there is a need to analyze ISO/IEC 12207 standard and ISO/IEC 15288 standard and refer to a new practical instruction for application that integrates common parts of them. For this, according to

the second meeting of MSC proceeded in March, 2015, Korea, Australia, and Japan have integrated the software quality assurance, human-oriented design, and evaluation for usability preparing for $\mathrm{e}^{-\mathrm{Navigation}} \mathrm{SQA} / \mathrm{HCD}$ 
guidelines. In order to be outstanding quality of SW in guideline, this guideline defines the processes to be proceeded through the lifetime of SW and specifies activities to be taken in each of the processes. In addition, it suggests a list of outcomes to be derived in each of the processes as well as a method of preparation so that users are able to create required outcomes. Lastly, it includes measurement matrix of product quality, data quality, and usage quality, estimates the characteristics of quality that our company prefers to emphasize, and suggests how to improve them if needed.

\subsection{Process Suggested in the Guideline}

(Figure 1) indicates activities for software quality suggested and approved in the NCSR meeting in March, 2014. This process indicates activities to be proceeded in each of the processes. In the stage of concept development, requirements of an interested party are defined, and software to be re-used in other types of software while proceeding a project is investigated. $\mathrm{Re}^{-}$usage of software is classified into two types. One of them is to apply software realized in other projects according to its functions when manufacturing the software, and the other is to create an independent software so that currently proceeding software is applied on other projects. In the stage 1 , the former case of re-usage of software is represented. In the planning and analysis stage, Stage 2, system requirements are analyzed applying the re-usage of former case of software. System requirements are to analyze whether systems for making software operate are to be applied on the environment for establishing software. Therefore, as requirements of an interested party, it is more of an implementation of analysis rather than definition .

Stage 3: In the design stage, system's architecture is designed and realized. In addition, former case of software re-usage is implemented applying the software re-used in the stage of realization. Stage 4: In the integration and testing stage, systems for performing each of the functions are integrated to implement the qualification testing for the relevant system. If there is no defect on the system according to the result of testing, system is installed on the software. In addition, software application is supported so that software and system are well-matched and managed. Stage 5: In the operation stage, software is operated, and repair and maintenance are implemented. If there are the improvements of software identified when proceeding the repair and maintenance, the relevant feedback is performed in the Analysis Operational System Feedback stage. After analyzing the feedback in this stage, work is repeated by going back to the Stage 1. Lastly, in the disposal stage, the process is proceeded when all types of software serve their functions and are to be disposed. In order to dispose software, strategies need to be established, and then disposing them according to procedures. However, a separate work is required to re-use software to be independently proceeded in the software prior to disposing them.

\section{Tools Overview}

\subsection{Backgrounds of Using the Tools}

In order for companies or groups to operate IT, various components including system software, application software, hardware, network development team, operation team, and supporting team are required. However, it is needed to individually manage relevant solutions to control such various components. There has been much difficulty in integration and connected management of them. SoftManager is an Enterprise Configuration Management Tool (ECMT) that overall manages the entire resources of IT 
(Figure 2) Deployment Diagram for CI system

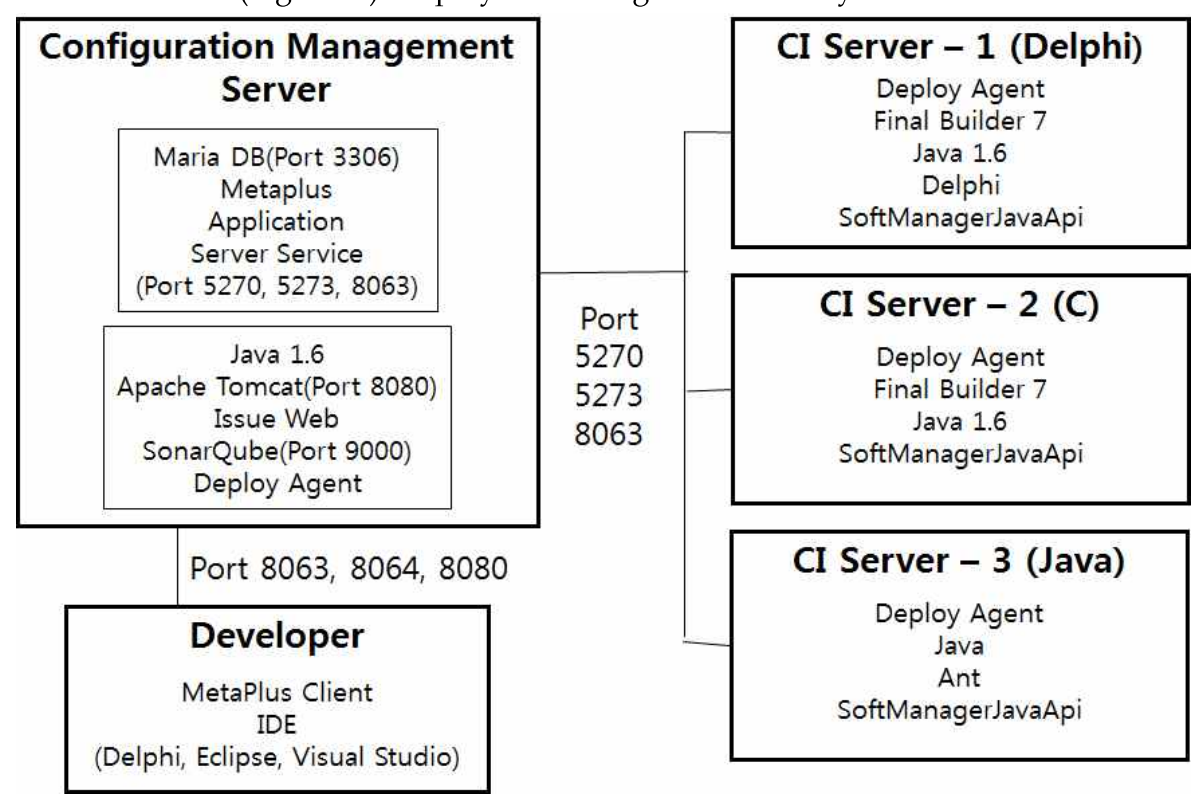

including software, hardware, and personnel resources.

This tool visually traces requirements from when there is a requirement to when the development is completed while proceeding a project aiming to manage requirement-oriented quality control. For this, major processes and outcomes to be applied on the development of pilot project are defined and applied on the system.

\subsection{Usage of Tools}

Lists in the Table 1 are required to use CI tools, and there is each of the unique functions. Following processes can be proceeded by utilizing the programs.

(1) Issue (request for changes) management

By managing issues including request for changes/bug/history of improvement of work process to be expanded, the function for recording detailed grounds on the changes in software to utilize them in the future by users.

(2) Configuration management Functions for managing source version to occur in the joint development and parallel development, image, outcomes, and configuration resources in various formats.

(3) Manage distribution and build

Functions for distributing approved distribution modules in the multiple remote operation servers by providing intuitive distribution management and identifying the current status of distribution for each of the operation servers and versions at a glance.

(4) Service control management

Functions for controlling the access of SSH (Secure SHell), FTP (File Transfer Protocol), terminal service, client, and RDB (Relational DataBase) needed in the stage of development and repair/maintenance.

\section{(5) Test management}

Functions for supporting the QA (Quality Assurance) checklist and tester needed in the testing stage/connecting with external tester 
$<$ Table 1> Setup list

\begin{tabular}{|c|c|c|}
\hline $\begin{array}{l}\text { Name of } \\
\text { Server }\end{array}$ & Installation Program & Usage \\
\hline \multirow{6}{*}{$\begin{array}{l}\text { Configuration } \\
\text { management } \\
\text { server }\end{array}$} & Sonar Qube & Perform static analysis \\
\hline & Meta Plus & Perform CI central service \\
\hline & Maria DB & DB for CI tools \\
\hline & Tomcat & Perform IssueWeb service \\
\hline & JAVA 1.6 & $\begin{array}{l}\text { Operate Tomcat service } \\
\text { Operate Deploy Agent }\end{array}$ \\
\hline & Deploy Agent & $\begin{array}{c}\text { Distribute source for static } \\
\text { analysis }\end{array}$ \\
\hline \multirow{5}{*}{$\begin{array}{l}\text { Delphi } \\
\text { automatic build } \\
\text { server }\end{array}$} & Delphi XE & Delphi compiler \\
\hline & Final Builder 7 & Perform to build Delphi \\
\hline & JAVA 1.6 & Operate Deploy Agent \\
\hline & Deploy Agent & $\begin{array}{l}\text { Distribute files to be built and } \\
\text { perform the building procedures }\end{array}$ \\
\hline & Soft ManagrJavaapi.jar & $\begin{array}{c}\text { Sync for files completed with } \\
\text { building }\end{array}$ \\
\hline \multirow{4}{*}{$\begin{array}{l}\mathrm{C} \text { automatic } \\
\text { build server }\end{array}$} & MS Build & C compiler \\
\hline & JAVA 1.6 & Perform Deploy Agent \\
\hline & Deploy Agent & $\begin{array}{l}\text { Distribute files to be built and } \\
\text { perform the building procedures }\end{array}$ \\
\hline & SoftManagrJavaapi.jar & $\begin{array}{c}\text { Sync for files completed with } \\
\text { building }\end{array}$ \\
\hline \multirow{4}{*}{$\begin{array}{l}\text { Java build } \\
\text { server }\end{array}$} & JAVA 1.x & $\begin{array}{l}\text { Perform Deploy Agent } \\
\text { Java compiler } \\
\text { (Need the confirmation of } \\
\text { version) }\end{array}$ \\
\hline & Ant & Perform to build Java \\
\hline & Deploy Agent & $\begin{array}{l}\text { Distribute files to be built and } \\
\text { perform the building procedures }\end{array}$ \\
\hline & SoftManagrJavaapi.jar & $\begin{array}{c}\text { Sync for files completed with } \\
\text { building }\end{array}$ \\
\hline
\end{tabular}

tools, or improving the quality of software by providing self-automatic tester tools.

(6) Manage users of external enterprises

Configure information of company adopting configuration management and also confirmative firms, user of confirmative firms, register customer requirements, and manage the proceedings of outsourcing development.

\subsection{Advantages to Obtain After Using Tools}

There are many of the advantages to obtain when using CI tools.

First of all, the process for extracting and negotiating the requirements is defined in the beginning. Therefore, it is feasible to extract appropriate requirements for the objective of a project and clarify details of technologies for supporting them. Hereupon, it is possible not only to more conveniently visualize requirements but also to make technologies as assets. Secondly, it is feasible to utilize extracted requirements using simulation tools and deriving additional requirements from them. The more seamlessly this work proceeds, the more likely it is for outcomes of a project to fulfill matters preferred by derived requirements. Lastly, it is possible to provide convenience for users by utilizing automatic tools to be connected with issues/requirements, configuration management, and test automatic tools. 
$<$ Table 2> Defined SW Process

\begin{tabular}{|c|c|c|c|}
\hline $\begin{array}{l}\mathrm{Nu} \\
\mathrm{mb} \\
\mathrm{er}\end{array}$ & $\begin{array}{l}\text { Name of } \\
\text { Phase }\end{array}$ & Explanation & $\begin{array}{l}\text { Charging } \\
\text { Person }\end{array}$ \\
\hline 1 & $\begin{array}{c}\text { Register } \\
\text { Requirements }\end{array}$ & $\begin{array}{l}\text { Define and register each of the units for } \\
\text { realization on the functional requirements }\end{array}$ & $\mathrm{PM}$ \\
\hline 2 & $\begin{array}{c}\text { Review } \\
\text { Requirements }\end{array}$ & $\begin{array}{l}\text { Review the registered requirements/ Enter } \\
\text { difference and reviewed opinion }\end{array}$ & PL \\
\hline 3 & $\begin{array}{r}\text { Assign } \\
\text { Developer }\end{array}$ & $\begin{array}{l}\text { Assign the work to developer about requirements } \\
\text { completed with review }\end{array}$ & PL \\
\hline 4 & Implementation & $\begin{array}{l}\text { Perform configuration management on the } \\
\text { modified/added resources as well as development of } \\
\text { requirements and enter processed contents }\end{array}$ & Developer \\
\hline 5 & Perform Test & $\begin{array}{c}\text { Perform the test on the realized contents based on } \\
\text { the negative test }\end{array}$ & Tester \\
\hline 6 & $\begin{array}{l}\text { Confirm } \\
\text { Processed } \\
\text { Contents }\end{array}$ & $\begin{array}{l}\text { Final confirm the processed contents on the } \\
\text { requirements completed with realization }\end{array}$ & $\mathrm{PL} / \mathrm{PM}$ \\
\hline 7 & Simulation & $\begin{array}{c}\text { Confirm the maintenance by equipping the contents } \\
\text { completed with realization on the simulation } \\
\text { equipment }\end{array}$ & User \\
\hline 8 & Termination & Termination of process & \\
\hline
\end{tabular}

\section{Utilization of CI Tools on the Maritime SQA}

\subsection{Definition of Development Process}

Previous SW process defined in the CI tool is represented by total eight stages in Table 2. Roles in each of the stages are determined. Previous stages are completed prior to moving to the next stage. In the requirements registration stage, functional requirements needed or performed in each of the software units are defined and registered. In the requirement review stage, defined and registered requirements are reviewed and approved with PL (Project Leader) conveying matters needed for requirements to developers. When the review on such requirements is completed, works are assigned to developers who participate in the project under control of $\mathrm{PL}$ according to each of the requirements, and developers realize them by reflecting defined requirements and review opinions. Developers assigned with a role in the work perform configuration management on the resources modified/added when realizing them and enter processed contents on the program. Test performance stage is proceeded based on negative test for detecting the errors on realized contents. When ultimately confirming the processed contents of requirements based on the test result, they are installed on the simulation equipment to make users confirm them and terminate the process.

\subsection{Improvement of Development Process}

In order to apply processes defined in 3.2 to maritime SQA tools, several modifications are required. This is because defects or areas for improvement of software are to be explored and applied from the beginning by reviewing requirements in the use of prototype on 
(Figure 3) Updated Process

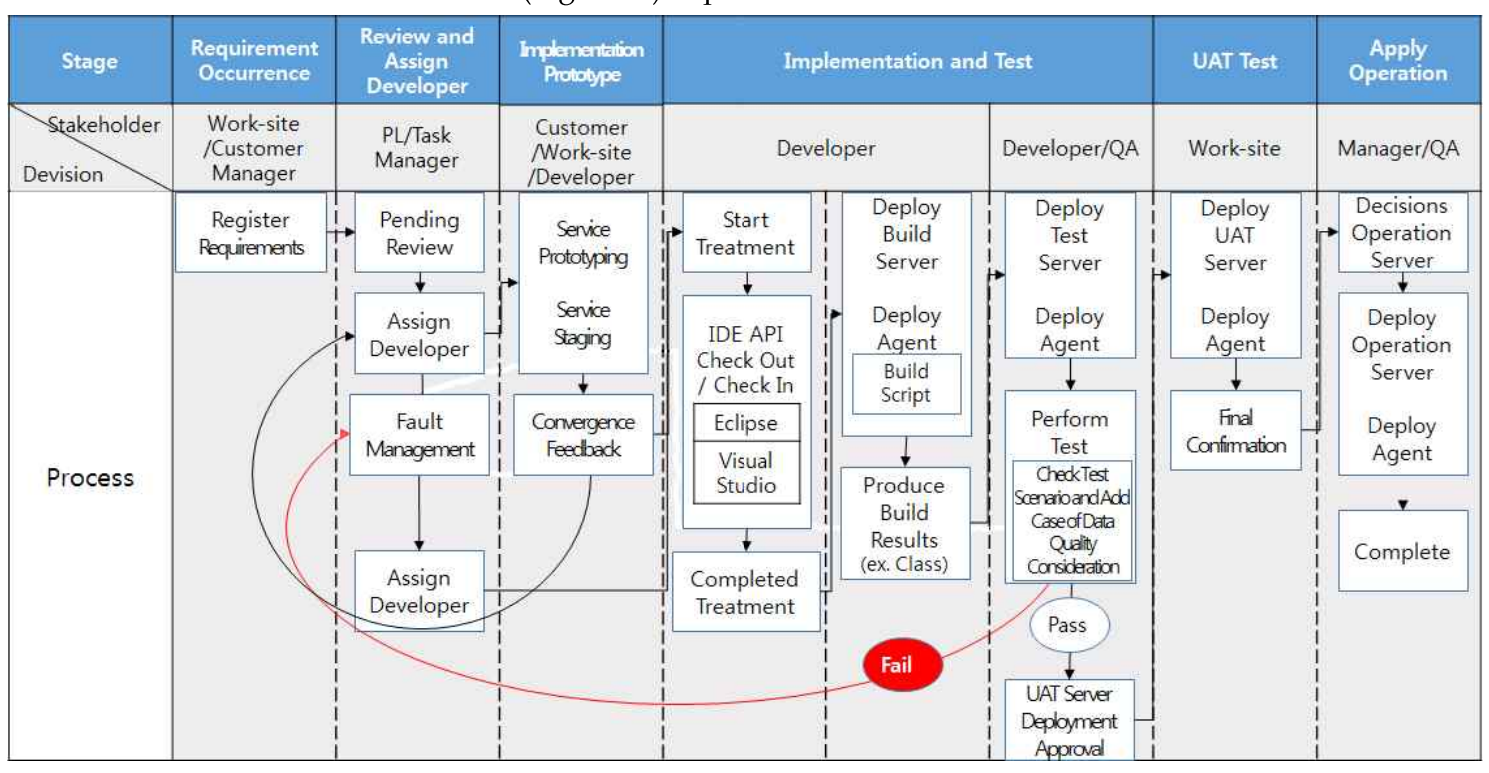

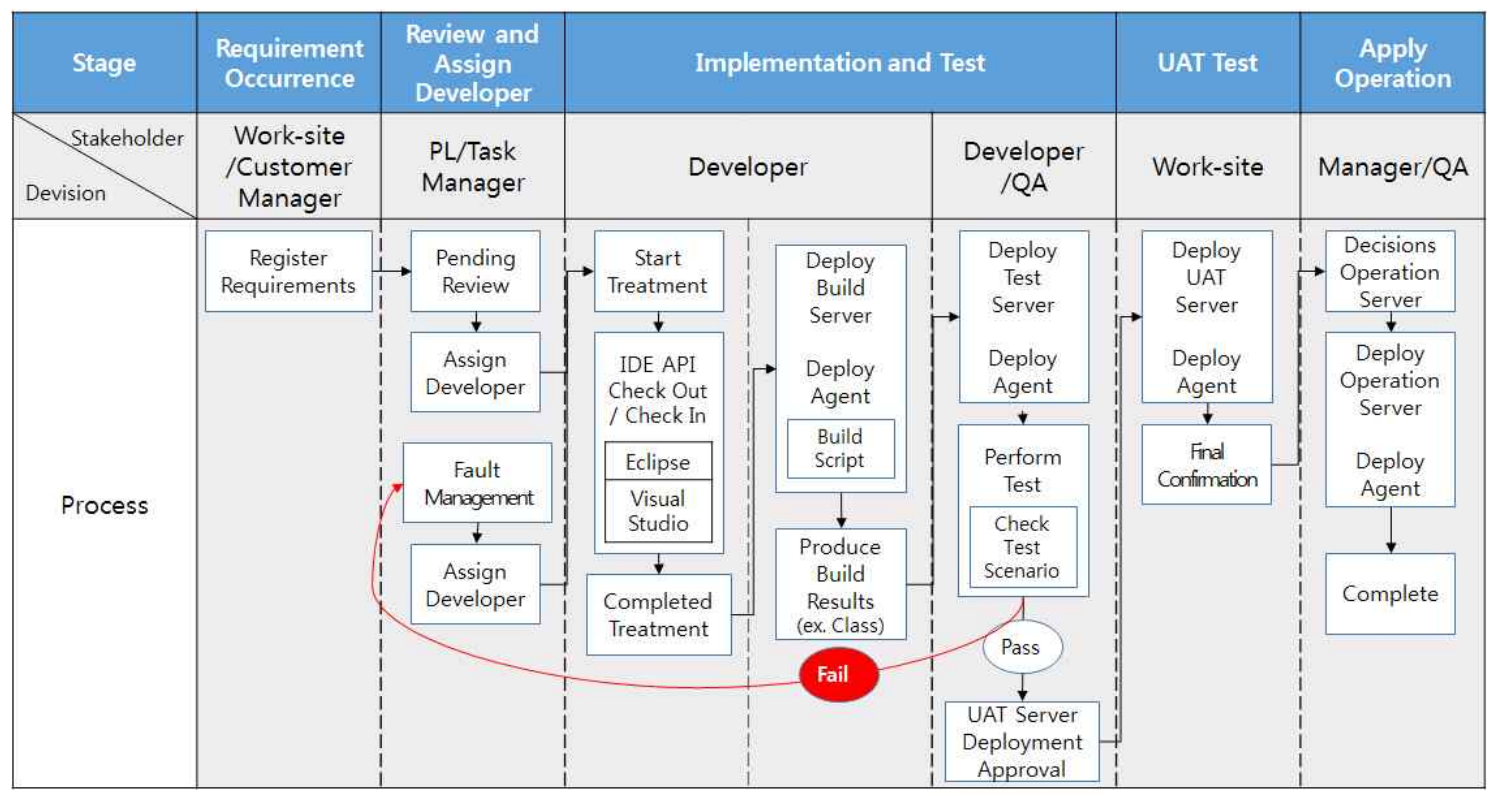

users or interested parties prior to development. There are several ways to manufacture the prototype models and proceed experiments. Here, two ways have been applied to the process. First of all, it is the service prototype for proceeding a role play by having users utilize relevant products in person in the place where is similar with actual environment as much as possible. Service prototype is a model where users are able to obtain a deeper understanding on the service since there is a model that users can utilize and manage in person.

Secondly, it is the service staging for realizing the scenario in the use of prototype with developers and users in the presence of 
multiple interested parties. Service staging has an advantage of receiving feedback from various interested parties by repeating it with changes in the roles multiple times. In addition, since it is possible to identify usability and review scenario, service staging has been frequently used. By adding the realization of prototype to the process, it is feasible to utilize feedback obtained from users and each of the interested parties managing requirements and defects.

(Figure 2) represents a process before and after making changes to apply previous software to maritime SQA. For the improvement of quality for usage, prototype is realized collecting feedback suggested by users and developers and realizing a new prototype. Based on improved prototype hereof, development stage is proceeded. In addition, process has been improved by adding the test case in consideration of data quality according to test plans for the improvement of data quality.

\section{Conclusion}

In this study, processes and outcomes were defined on pilot project in the perspective of utilizing CI tools to improve maritime software quality and applied on the system. For the improvement of data quality and usability quality emphasized in the quality of maritime software, a separate stage where customers confirmed the prototype has been added. For the improvement of data quality, test case has been added on the test plans which considered data quality. In order to utilize commonly used $\mathrm{CI}$ tools to the improvement of maritime software quality, it is required to proceed a customizing procedure of CI tools for the management of appropriate processes and outcomes in the maritime field. In addition, there is a need to reflect feedbacks derived from continuous usage and internalization of pilot project to CI frameworks and hence improve them afterwards.

\section{References}

[1] S. Lee, J. Jung, H. Kim, S.Lim, "A Method of Integrat ing the e-Navigation SQA Guideline and HCD," Jou rnal of the Korean Society of Marine Environment \& Safety, pp.157-159, April 2015

[2] R.IMO MSC.1/Circ. 1512, Guideline on Software Qua lity Assurance and Human-Centred Design for $\mathrm{e}^{-\mathrm{N}}$ avigation

[3] IMO(2014), "Report of the $\mathrm{e}^{-}$Navigation draft guideli nes harmonization Correspondence Group" NCSR, $2 / 6$.

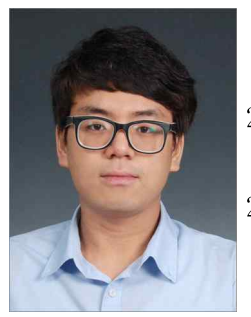

임 상 우

2008년 2014 : 한국해양대학교 IT공학부 재학

2015년 현재 : 한국해양대학교 대학원 컴퓨터공학과 재학

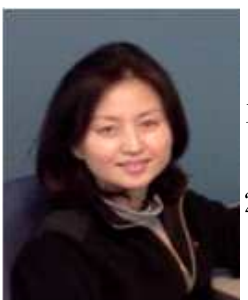

이 서 정

1998 2003 : 동덕여자대학교 강의 교수

2005현재 : 한국해양대학교 해사 IT공학부 부교수

2010 현재 : 한국IT서비스학회 이사

2008 현재 : 국토해양부 IMO 항해안전 전문위원회

및 항해통신 - 수색구조 전문위원회 정부대표 단

관심분야: 소프트웨어 개발 방법론, 소프트웨어 통 합, $\mathrm{e}^{-N a v i g a t i o n ~ ㅅ ㅗ ㅍ ㅡ ㅌ ㅡ ㅇ ㅞ ㅇ ㅓ ~ ㅍ ㅜ ㅁ ㅈ ㅣ ㄹ ~}$ 